\title{
Analisis Kemampuan Pemecahan Masalah Matematis : Dampak Model Pembelajaran SAVI ditinjau dari Kemandirian Belajar Matematis
}

\author{
Evi Dwi Murti ${ }^{1}$, Nasir ${ }^{1}$, Hasan Sastra Negara ${ }^{1}$ \\ ${ }^{1}$ Universitas Islam Negeri Raden Intan Lampung. Jalan Endro Suratmin, Sukarame, Bandar \\ Lampung 35133, Indonesia. \\ * Corresponding Author. E-mail: edwimurti709@gmail.com
}

\begin{abstract}
Abstrak
Penulisan ini bertujuan untuk melihat pengaruh dari penggunaan model pembelajaran SAVI terhadap kemampuan pemecahan masalah peserta didik. Adapun Jenis penulisan ini adalah penulisan kuantitatif. Teknik pengambilan sampel yang digunakan adalah acak kelas. Teknik pengumpulan data yang digunakan adalah teknik tes uraian (essay). Teknik analisis data yang digunakan adalah uji anava dua jaur. Berdasarkan uji hipotesis yang didapat diperoleh hasil bahwa terdapat pengaruh peserta didik dengan perlakuan menggunakan model pembelajaran SAVI terhadap peningkatan kemampuan pemecahan masalah matematis pada materi faktorisasi aljabar lebih baik dibandingkan dengan peserta didik dengan perlakuan pembelajaran menggunakan pembelajaran konvensional baik secara umum maupun ditinjau pada masingmasing kategori kemandirian belajar matematis peserta didik. Terdapat interaksi kemampuan pemecahan masalah matematis peserta didik yang memiliki kemandirian belajar matematis tinggi lebih baik daripada peserta didik yang memiliki kemandirian belajar matematis sedang maupun rendah. Sedangkan peserta didik yang memiliki kemandirian belajar matematis yang lebih baik daripada peserta didik yang memiliki kemandirian belajar matematis rendah. Selain itu tidak terdapat interaksi antara perlakuan pembelajaran dan kategori kemandirian belajar matematis peserta didik terhadap peningkatan kemampuan pemecahan masalah matematis peserta didik. Kata kunci: Kemampuan Pemecahan Masalah, Model Pembelajaran SAVI, Kemandirian
\end{abstract}

\begin{abstract}
This writing aims to see the effect of using the SAVI learning model on students' problem solving abilities. The type of writing is quantitative writing. The sampling technique used was randomized class. The data collection technique used is the essay test technique. The data analysis technique used is the two jaur anava test. Based on the hypothesis test obtained, the results show that there are influences of students with treatment using the SAVI learning model to improve mathematical problem solving skills in algebraic factorization material better than students with the treatment of learning using conventional learning both in general and in each category. the independence of students' mathematical learning. There is interaction between mathematical problem solving abilities of students who have high mathematical learning independence better than students who have moderate and low mathematical learning independence. While students who have mathematical learning independence are better than students who have low mathematical learning independence. In addition, there is no interaction between the treatment of learning and the category of self-reliance on students 'mathematical learning towards improving students' mathematical problem solving abilities.
\end{abstract}

Keywords: Problem Solving Ability, SAVI Learning Model, Independence

\section{PENDAHULUAN}

Pentingnya kemandirian belajar bagi siswa dalam proses pembelajaran matematika karena tuntutan kurikulum agar siswa dapat menghadapi persoalan di dalam kelas maupun di luar kelas yang semakin kompleks dan mengurangi ketergantungan siswa dengan orang lain dalam kehidupan sehari-hari (Ayuningtyas, 2015). Kemandirian adalah 
individu yang mampu menghadapi masalah-masalah yang dihadapinya dan mampu bertindak secara dewasa (Fahradina, Ansari, \& Saiman, 2014). Menurut (Irawan, 2015) dalam penelitiannya mengungkapkan bahwa ciri utama belajar mandiri adalah adanya pengembangan kemampuan siswa untuk melakukan proses belajar yang tidak tergantung pada faktor guru, teman, kelas dan lain-lain. Tingkat kemandirian belajar siswa dapat ditentukan berdasarkan seberapa besar inisiatif dan tanggung jawab siswa untuk berperan aktif dalam hal perencanaan belajar, proses belajar maupun evaluasi belajar (Qohar, 2010). Maka dapat disimpulkan semakin besar peran aktif siswa dalam berbagai kegiatan tersebut, mengindikasikan bahwa siswa tersebut memiliki tingkat kemandirian belajar yang tinggi.

Menanggapi hal itu kemandirian belajar matematika tentu sangat penting untuk kemampuan pemecahan masalah matematis peserta didik. Karena menurut (Novianti, 2017) tujuan pemecahan masalah dalam matematika adalah untuk meningkatkan kesediaan siswa dalam memperbaiki kemampuan mereka saat memecahkan masalah dan membuat siswa sadar akan strategi pemecahan masalah. Menurut (Astuti, Yuanita, \& Anggraini, 2018) kemampuan pemecahan masalah akan membuat peserta didik sadar bahwa banyak masalah dapat dipecahkan lebih dari satu cara. Menurut (Noviyana \& Fitriani, 2018) Kemampuan pemecahan masalah setiap siswa pasti berbeda-beda dan tergantung tingkat kecerdasan yang dimiliki oleh siswa. (Ramadhani, 2017) juga mengatakan bahwa prestasi belajar siswa dipengaruhi oleh faktor internal yaitu kecerdasan, bakat, dan minat, serta motivasi individu.

Mengingat setiap peserta didik mempunyai taraf berpikir yang berbeda dan adanya kesulitan peserta didik dalam memecahkan masalah, maka keterampilan dan keahlian yang dimiliki seorang guru diharapkan mampu memilih model pembelajaran yang tepat agar peserta didik menguasai pembelajaran sesuai dengan target yang akan dicapai dalam kurikulum. Maka dalam hal ini penulis akan menerapkan model pembelajaran SAVI.

Model pembelajaran SAVI memiliki unsur unsur antara lain belajar dengan bergerak dan berbuat (Somatis), belajar dengan berbicara dan mendengar (Auditori), belajar dengan mengamati (Visual), belajar dengan memecahkan masalah dan berfikir (Intelektual) (Pratama, Nuryatin, Mardikantoro, \& Artikel, 2017). Dari hasil penulisan oleh (Khery \& Raodyatun, 2014) bahwa model pembelajaran SAVI memberikan respond yang aktif, komunikatif dan aktivitas yang baik dalam proses pembelajaran asam dan basa. Selain itu (Wati \& Darsana, 2014) dari hasil uji hipotesisnya dari penulisannya yang berjudul Pengaruh Model Pembelajaran Somatic, Auditory, Visual, Intelectual (SAVI) Berbantuan Bahan Ajar Terhadap Hasil Belajar IPS Siswa Kelas V SD Gugus Raden Ajeng Kartini, dengan hasil uji thit $=4,95>t_{\text {tab }}=$ 1,990 pada taraf signifikansi $5 \%$ dan $\mathrm{dk}=81$ yang berarti bahwa model SAVI mempunyai pengaruh terhadap dasil belajar IPS Siswa. Ditinjau dari hasil belajar matematika dengan menggunakan model SAVI telah dijelaskan dari hasil penelitian oleh (Alfiani, 2016; Suratman, 2015; Sutarna, 2018) yang mengungkapkan bahwa hasil belajar peserta didik terlihat mengalami peningkatan yang lebih baik diantara faktanya peserta didik sudah mampu mencapai KKM yang telah ditentukan.

Berdasarkan penelitian terdahulu, pengaruh model pembelajaran SAVI banyak digunakan dalam proses belajar mengajar (Afriawan, Binadjab, \& Latifahb, 2012; Arsani, Suarni, \& Kusmaryatni, 2017; Haruminati, Suarni, \& Sudarma, 2016; Indrawan, Kristiantari, \& Negara, 2018; Kusumantara, Santyadiputra, \& Sugihartini, 
2017; Maulaholo \& Haryudo, 2015; Nurhayati \& Windayana, 2017; Rosalina \& Pertiwi, 2018; Sutarna, 2018; Wati, Darsana, \& Suardika, 2014; Wijayanti \& Prayitno, 2013). Selain model pembelajaran SAVI, masih banyak model pembelajaran lain yang bisa mempengaruhi kemampuan pemecahan masalah dalam proses belajar mengajar, seperti penelitian dari (Amir, 2015; Dwi, Arif, \& Sentot, 2013; Hakim, 2014; Muchlis, 2012; Muslim, 2015; Noviyana \& Fitriani, 2018; Seruni, 2018; Setiawan \& Harta, 2014; Susanti \& Nurfitriyanti, 2018; Syazali, 2015; Wulandari, Mujib, \& Putra, 2016; Zulfah, 2017)

Penelitian-penelitian diatas belum pernah dilakukan penelitian untuk melihat pengaruh model SAVI terhadap kemampuan pemecahan masalah peserta didik, sehingga keterbaharuan penulis adalah dengan tujuan melihat pengaruh model SAVI terhadap kemampuan pemecahan masalah peserta didik ditinjau dari kemandirian belajar.

\section{METODE}

Metode penelitian yang digunakan pada penelitian ini adalah menggunakan penelitian eksperimen karena penulis akan mencari perbedaan treatment (perlakuan) tertentu dengan desain penelitian posttest-only control design. Bagan desain penelitian dapat dilihat pada Tabel 1.

Tabel 1. Desain Penelitian

\begin{tabular}{lccc}
\hline \multicolumn{1}{c}{ Perlakuan $\left(\boldsymbol{A}_{\boldsymbol{i}}\right)$} & \multicolumn{3}{c}{ Kemandirian Belajar $\left(\boldsymbol{B}_{\mathbf{j}}\right)$} \\
Model Pembelajaran SAVI $\left(A_{1}\right)$ & Tinggi (B) & Sedang $\left(\mathbf{B}_{\mathbf{2}}\right)$ & Rendah $\left(\mathbf{B}_{\mathbf{3}}\right)$ \\
Pembelajaran Konvensional & $A_{1} B_{1}$ & $A_{1} B_{2}$ & $A_{1} B_{3}$ \\
& $A_{2} B_{1}$ & $A_{2} B_{2}$ & $A_{2} B_{3}$ \\
\hline
\end{tabular}

Tehnik pengambilan sampel yang digunakan adalah tehnik acak kelas yang terdiri dari kelas eksperimen (kelas yang medapat perlakuan model $S A V I$ ) dan kelas control (kelas yang medapatkan perlakuan metode konvensional). Populasi dalam penelitian ini adalah seluruh peserta didik kelas VIII semester genap SMP Negeri 2 Baradatu pada tahun ajaran 2018 yang terdiri dari delapan kelas. Teknik pengumpulan data menggunakan tes, wawancara dan angket. Sedangkan teknik analisis data yang digunakan adalah uji prasarat yaitu uji normalitas dan homogenitas lalu dilakukan uji anava dua jalan.

\section{HASIL DAN PEMBAHASAN}

Berdasarkan hasil pengolahan data hasil tes kemampuan pemecahan masalah matematis peserta didik dengan analisis deskriftif, diperoleh rekapitulasi hasil deskripsi amatan dapat dilihat pada Tabel 2.

Tabel 2. Hasil Deskripsi Amatan Kemampuan Pemecahan Masalah Matematis

\begin{tabular}{cccccccc}
\hline Kelas & $\boldsymbol{X}_{\text {maks }}$ & $\boldsymbol{X}_{\text {min }}$ & \multicolumn{2}{c}{ Ukuran Tendensi Sentral } & \multicolumn{2}{c}{$\begin{array}{c}\text { Ukuran Variansi } \\
\text { Kelompok }\end{array}$} \\
& & & $\overline{\boldsymbol{x}}$ & $\mathbf{M}_{\mathbf{e}}$ & $\mathbf{M}_{\mathbf{0}}$ & $\mathbf{N}$ & SD \\
Eksperimen & 96 & 67 & 77 & 76 & 87 & 31 & 7,7 \\
Kontrol & 87 & 57 & 69,46 & 70 & 60 & 30 & 9,5 \\
\hline
\end{tabular}

Berdasarkan Tabel 2, kelas eksperimen diperoleh nilai rata-rata sebesar 77, sedangkan pada kelas kontrol diperoleh nilai rata-rata sebesar 69,46. Dari nilai tersebut terlihat bahwa kemampuan pemecahan masalah matematis kedua kelas memiliki perbedaan. Nilai kelas eksperimen lebih tinggi di bandingkan dengan nilai kelas kontrol, artinya kelas eksperimen 
Desimal, 2 (2), 2019 - 122

Evi Dwi Murti, Nasir, Hasan Sastra Negara

mempunyai kecenderungan kemampuan pemecahan masalah matematis yang lebih tinggi di bandingkan kelas kontrol. Hasil kemampuan pemecahan masalah matematis peserta didik kelas eksperimen dan kontrol memiliki perbedaan yang cukup signifikan terlihat bahwa kelas eksperimen yang menggunakan model pembelajaran SAVI (Somatic, Auditory, Visuallization, and Intellectualy) karena peserta didik cenderung lebih aktif dalam proses pembelajaran.

Selain dari pengolahan dan analisis data kemampuan pemecahan masalah matematis peserta didik ditinjau juga dari analisis data kemandirian peserta didik. Data rentang nilai kelas eksperimen menunjukkan bahwa peserta didik yang pada kategori tinggi sebesar $29 \%$ kemudian pada kategori sedang diperoleh persentase sebesar $45 \%$ dan pada kategori tinggi sebesar 25\%. Data rentang nilai kelas kontrol menunjukkan bahwa peserta didik yang pada kategori tinggi sebesar 16,67\% kemudian pada kategori sedang diperoleh persentase sebesar $30 \%$ dan kategori sedang sebesar 53,33\%. Setelah diketahui data amatan kemampuan pemecahan masalah matematis dan rentan nilai kemandirian peserta didik pada kelas eksperimen dan control maka akan diketahui hasil tes kemampuan pemecahan masalah matematika dan kemandirian belajar matematika digunakan untuk menjawab hipotesis penelitian. Uji hipotesis yang digunakan dalam penelitian yaitu anova dua jalur. Sebelum melakukan pengujian penelitian, dilakukan uji prasyarat. Uji prasyarat dalam penelitian meliputi uji normalitas dan uji homogenitas. Uji normalitas digunakan untuk mengetahui data berdistribusi normal atau tidak. Setelah diketahui data penelitian berdistribusi normal maka dilakukanlah uji homogenitas yaitu untuk mengetahui data yang diperoleh memiliki varian yang homogen atau tidak. Adapun rekapitulasi nilai hasil uji normalitas dapat dilihat pada Tabel 3.

Tabel 3. Hasil Uji Normalitas Data Postes Kelas Eksperimen dan Kelas Kontrol

\begin{tabular}{lllll}
\multicolumn{1}{c}{ Karakteristik } & \multicolumn{2}{c}{ Nilai } & Hasil & Interpretasi \\
& Eksperimen & Kontrol & & \\
Lhitung & 0,1179 & 0,1527 & Lhitung $\leq$ Ltabel & Berdistribusi normal \\
Ltabel & 0,1559 & 0,1590 & & \\
& $(0,05 ; 31)$ & $(0,05 ; 30)$ & & \\
\hline
\end{tabular}

Berdasarkan Tabel 3 didapatkan hasil uji normalitas Liliefors postes di atas, dari jumlah sampel kelas eksperimen 31 peserta didik dan kelas kontrol sebanyak 30 peserta didik dengan taraf $\alpha=0,05$. Kolom keputusan dibuat berdasarkan pada ketentuan pengujian normalitas, yaitu Lhitung $\leq$ Ltabel maka dinyatakan data berdistribusi normal. Sebaliknya jika Lhitung $\geq$ Ltabel maka data dinyatakan tidak berdistribusi normal. Dari tabel normalitas diatas untuk kelas eksperimen diperoleh hasil uji normalitas Lhitung $\leq$ Ltabel postes yaitu $0,1179 \leq 0,1559$ maka data berdistribusi normal sehingga $\mathrm{H}_{0}$ diterima. Pada kelas kontrol diperoleh hasil uji normalitas untuk Lhitung $\leq$ Ltabel yaitu $0,1527<0,1590$ maka data berdistribusi normal sehingga $\mathrm{H}_{0}$ diterima yang dapat dilihat pada Tabel 4 .

Tabel 4. Hasil Uji Normalitas Data Postest Kemandirian Belajar

\begin{tabular}{|c|c|c|c|c|c|}
\hline Karakteristik & Tinggi & $\begin{array}{l}\text { Nilai } \\
\text { Sedang }\end{array}$ & Rendah & Hasil & Interpretasi \\
\hline Lhitung & 0,1300 & 0,0826 & 0,1632 & Lhitung & Berdistribusi \\
\hline Ltabel & $\begin{array}{c}0,2257 \\
(0,05 ; 14)\end{array}$ & $\begin{array}{c}0,1590 \\
(0,05 ; 30) \\
\end{array}$ & $\begin{array}{c}0,2071 \\
(0,05 ; 17)\end{array}$ & $\leq$ Ltabel & normal \\
\hline
\end{tabular}


Uji normalitas tidak hanya dilakukan pada kelas kontrol dan eksperimen dalam pemecahan masalah matematis melainkan juga dari kemandirian belajar peserta didik yang telah dibagi kedalam tiga kategori yaitu tinggi, sedang dan rendah dimana dalam hal ini kategori tersebut merupakan penggabungan antara kelas kontrol dan eksperimen. Berdasarkan Tabel normalitas diatas untuk kategori tinggi diperoleh hasil uji normalitas Lhitung $\leq$ Ltabel postes yaitu $0,1300 \leq 0,2257$ maka data berdistribusi normal sehingga $\mathrm{H}_{0}$ diterima. Kategori sedang diperoleh hasil uji normalitas untuk Lhitung $\leq$ Ltabel yaitu $0,0826<0,1590$ maka data berdistribusi normal sehingga $\mathrm{H}_{0}$ diterima dan pada kelas rendah yaitu 0,1632 $<0,2071$ maka data berdistribusi normal yang dapat dilihat pada Tabel 5 .

Tabel 5. Hasil Uji Homogenitas Data Postes Kelas Eksperimen dan Kelas Kontrol

\begin{tabular}{lccc}
\hline \multicolumn{1}{c}{ Karakteristik } & Hasil uji homogenitas & Hasil & Interpretasi \\
$\mathbf{F}_{\text {hitung }}$ & 1,2344 & F & Homogen \\
$\mathbf{F}_{\text {tabel }}$ & 1,8474 & & \\
\hline
\end{tabular}

Nilai $F_{\text {tabel }}$ diambil berdasarkan nilai pada tabel kritis F untuk uji Fisher pada taraf signifikan $5 \%(0,05)$ dengan $\mathrm{df}_{1}=30$ dan $\mathrm{df}_{2}=29$ diperoleh $F_{\text {hitung }}$ sebesar 1,8474. Kolom keputusan dibuat berdasarkan pada ketentuan pengujian homogenitas, yaitu jika Fhitung $\leq$ Ftabel maka $1,2344 \leq 1,8474$ sehingga $\mathrm{H}_{0}$ diterima yang artinya data memiliki varians yang homogen. Uji homogenitas tiga varian juga diperlukan guna menggunakan uji anova dua jalur, berikut ini hasil homogenitas 3 kategori kemandirian belajar peserta didik dapat dilihat pada Tabel 6 .

Tabel 6. Hasil Uji Homogenitas Data Kemandirian Belajar

\begin{tabular}{lccc} 
Karakteristik & Hasil uji homogenitas & Hasil & Interpretasi \\
F $_{\text {hitung }}$ & 1,7909 & Fhitung $\leq$ Ftabel & Homogen \\
$\mathbf{F}_{\text {tabel }}$ & 5,9915 & & \\
\hline
\end{tabular}

Uji homogenitas kriteria kemandirian belajar peserta didik menunjukkan bahwa Fhitung < Ftabel sehingga dapat disimpulkan bahwa ketiga kriteria tersebut memiliki varians yang sama. Setelah memenuhi prasyarat uji normalitas dan homogenitas maka uji anova dua jalur dapat dilakukan.
Uji anava 2 jalur digunakan untuk melihat apakah terdapat pengaruh penggunaan model SAVI terhadap kemampuan pemecahan masalah matematis ditinjau dari kemandirian peserta didik. Adapun hasil uji anava 2 jalur dapat dilihat pada Tabel 7.

Tabel 7. Uji Anova Dua Jalur

\begin{tabular}{|c|c|c|c|c|c|c|c|c|c|c|}
\hline JKA & 592,848 & dkA & 1 & RKA & 592,848 & $\mathbf{F}_{\mathbf{a}}$ & 8,704 & $F_{\text {tabel }}$ & 4,016 & H0 Ditolak \\
\hline JKB & 727,640 & $\mathrm{dkB}$ & 2 & RKB & 363,820 & $\mathrm{~F}_{\mathrm{b}}$ & 5,342 & $\mathrm{~F}_{\text {tabel }}$ & 3,165 & H0 Ditolak \\
\hline JKAB & 36,570 & $\mathrm{dkAB}$ & 2 & RKAB & 18,285 & $\mathrm{~F}_{\mathrm{ab}}$ & 0,268 & $F_{\text {tabel }}$ & 3,165 & $\begin{array}{l}\text { H0 } \\
\text { Diterima }\end{array}$ \\
\hline JKG & 3746,040 & $\mathrm{dkG}$ & 55 & RKG & 68,110 & & & & & \\
\hline JKT & 5103,098 & $\mathrm{dkT}$ & 60 & & & & & & & \\
\hline
\end{tabular}


Seperti sudah diketahui sebelumnya bahwa terdapat tiga hipotesis yang akan disimpulkan dari penelitian ini diantaranya:

1. Hipotesis pertama (JKA) dapat dilihat bahwa nilai $F_{\text {hitung }}=8,704$ lebih besar dibanding $\mathrm{F}_{\text {tabel }}$ dengan df1(pembilang) =1 dan df2 (penyebut) $=55$ adalah 4.016 sehingga nilai $F_{\text {hitung }}>\mathrm{F}_{\text {tabel }}(8.704>$ 4.016) berarti perlakuan berpengaruh signifikan maka dapat disimpulkan bahwa Ho ditolak dan Ha diterima terdapat perbedaan pengaruh model pembelajaran SAVI terhadap kemampuan Pemecahan masalah matematis.

2. Hipotesis kedua (JKB) bahwa nilai $F_{\text {hitung }}=5$, 342 lebih besar dibanding $F_{\text {tabel }}$ dengan df1(pembilang) $=2$ dan $\mathrm{df} 2($ penyebut $)=55$ adalah 3.165 sehingga nilai Fhitung $>F_{\text {tabel }}(4,441>$ 3.165) berarti kelas berpengaruh signifikan maka dapat disimpulkan bahwa Ho ditolak dan Ha diterima sehingga terdapat perbedaan pengaruh model pembelajaran SAVI terhadap kemampuan Pemecahan masalah matematis dengan metode ceramah terhadap kemandirian belajar tinggi, sedang dan rendah.
3. Hipotesis ketiga untuk melihat interaksi (JKAB) mengenai interaksi antara bahwa nilai $F_{\text {hitung }}=0,268$ lebih kecil dibanding $F_{t a b e l}$ dengan df1(pembilang) $=2$ dan df2 (penyebut) $=55$ adalah adalah 3.165 sehingga nilai $F_{\text {hitung }}<F_{\text {tabel }}(0,268<$ adalah 3.165) maka dapat disimpulkan bahwa Ho diterima dan Ha ditolak sehingga maka dapat disimpulkan bahwa tidak terdapat interaksi antara pembelajaran model pembelajaran SAVI terhadap kemampuan Pemecahan masalah matematis dengan kemandirian belajar peserta didik (tinggi, sedang, dan rendah)

Setelah dilakukan uji anova dua jalur, perlu dilakukan lagi yaitu uji komparasi ganda dengan menggunakan metode schuffe'. tujuannya untuk melihat signifikansi perbedaan antara kemampuan pemecahan masalah matematis yang ditinjau dari kemandirian peserta didik yang dikategorikan dalam tiga kriteria yakni tinggi, sedang dan rendah. Hasil dari uji schuffe' dapat dilihat pada Tabel 8.

Tabel 8. Hasi Uji Schuffe'

\begin{tabular}{|c|c|c|c|c|c|}
\hline No & Interaksi & NPAPR & NKPR & Kriteria & Kesimpulan \\
\hline 1 & Tinggi_Sedang & 4,813 & 6,720 & $N P A P R \leq N K P R$ & Tidak Berbeda Signifikan \\
\hline 2 & Tinggi-Rendah & 9,083 & 7,493 & $N P A P R \geq N K P R$ & Berbeda Signifikan \\
\hline 3 & Sedang-Rendah & 4,270 & 6,303 & $N P A P R \leq N K P R$ & Tidak Berbeda Signifikan \\
\hline
\end{tabular}

a. Interaksi (Tinggi-Sedang), didapat bahwa $N P A P R \leq N K P R$ yang berarti tidak berbeda signifikan. Sehingga disimpulkan bahwa rerata yang diperoleh dari perlakuan pembelajaran dengan menggunakan model pembelajaran SAVI lebih baik dari pada perlakuan pembelajaran dengan menggunakan metode ceramah. Dengan demikian menunjukkan bahwa kemampuan pemecahan masalah matematis peserta didik yang diajarkan dengan menggunakan model pembelajaran SAVI lebih baik dari pada peserta didik yang diajarkan dengan menggunakan metode ceramah.

b. Interaksi (tinggi-rendah), didapat bahwa $N P A P R \geq N K P R$ yang berarti 
Desimal, 2 (2), 2019 - 125

Evi Dwi Murti, Nasir, Hasan Sastra Negara

tidak berbeda signifikan. Sehingga disimpulkan bahwa rerata yang diperoleh dari kategori kemandirian belajar tinggi lebih baik daripada rerata yang diperoleh dari kategori kemandirian belajar sedang dan rendah. Begitupun untuk rerata yang diperoleh dari kategori kemandirian belajar sedang lebih baik daripada rerata yang diperoleh dari kategori kemandirian belajar rendah. Dengan demikian menunjukkan bahwa kemampuan pemecahan masalah matematis peserta didik yang memiliki kemandirian belajar tinggi lebih baik daripada peserta didik yang memiliki kemandirian belajar sedang maupun rendah. Sedangkan peserta didik yang memiliki kemandirian belajar sedang menghasilkan kemampuan pemecahan masalah yang lebih baik daripada peserta didik yang memiliki kemandirian belajar rendah.

c. Namun tidak terdapat interaksi antara perlakuan pembalajaran dengan kategori kemandirian belajar peserta didik terhadap kemampuan pemecahan masalah matematis karena $\quad F_{\text {hitung }}<F_{\text {tabel }} \quad$ yang menunjukkan bahwa $\mathrm{H}_{0}$ diterima, berarti tidak terdapat perbedaan pengaruh antara perlakuan pembelajaran dan kemandirian belajar peserta didik terhadap kemampuan pemecahan masalah matematika, maka karakteristik perbedaan kemandirian belajar peserta didik terhadap matematika akan sama pada setiap perlakuan pembelajaran. Artinya kalau secara umum kemandirian belajar peserta didik tinggi lebih baik daripada kemandirian belajar peserta didik sedang dan rendah, sedangkan ditinjau dari perlakuan pembelajaran dengan menggunakan model pembelajaran SAVI juga akan berlaku kesimpulan kemandirian belajar peserta didik tinggi lebih baik daripada kemandirian belajar peserta didik sedang dan rendah. Demikian pula sama halnya dengan perlakuan pembelajaran dengan menggunakan metode ceramah, maka kemandirian belajar peserta didik tinggi lebih baik daripada kemandirian belajar peserta didik sedang dan rendah. Selanjutnya kemandirian belajar peserta didik tinggi akan lebih baik daripada kemandirian peserta didik sedang dan rendah ditinjau dari perlakuan pembelajaran dengan model pembelajaran SAVI dan metode ceramah. Dan kemandiriran belajar peserta didik sedang akan lebih baik daripada kemandirian belajar peserta didik rendah ditinjau dari perlakuan pembelajaran dengan model pembelajaran SAVI maupun metode ceramah.

Berbagai keterangan diatas menjadi salah satu penyebab mengapa penggunaan model pembelajaran SAVI mendapatkan respon yang lebih baik dan berpengaruh positif dalam meningkatkan kemampuan pemecahan masalah yang ditinjau dari kemandirian peserta didik dibandingkan dengan kelas kontrol yang menggunakan pendekatan metode ceramah secara relevan karena peserta didik secara aktif mampu mengeksplore dan mengembangkan dirinya dalam menjalankan kegiatan belajar mengajar di dalam kelas.

\section{SIMPULAN DAN SARAN}

Berdasarkan hasil analaisis dan pembahasan terhadap data penelitian menganai pengaruh model pembelajaran SAVI (Somatic, Auditory, Visuallization, Intellectualy) terhadap peningkatan kemampuan pemecahan masalah matematis ditinjau dari kemandirian belajar matematis peserta didik didapati 
bahwa terdapat pengaruh peserta didik dengan perlakuan menggunakan model pembelajaran SAVI terhadap peningkatan kemampuan pemecahan masalah matematis pada materi faktorisasi aljabar lebih baik dibandingkan dengan peserta didik dengan perlakuan pembelajaran menggunakan pembelajaran konvensional baik secara umum maupun ditinjau pada masing-masing kategori kemandirian belajar matematis peserta didik. Terdapat interaksi kemampuan pemecahan masalah matematis peserta didik yang memiliki kemandirian belajar matematis tinggi lebih baik daripada peserta didik yang memiliki kemandirian belajar matematis sedang maupun rendah. Sedangkan peserta didik yang memiliki kemandirian belajar matematis yang lebih baik daripada peserta didik yang memiliki kemandirian belajar matematis rendah. Selain itu tidak terdapat interaksi antara perlakuan pembelajaran dan kategori kemandirian belajar matematis peserta didik terhadap peningkatan kemampuan pemecahan masalah matematis peserta didik.

Berdasarkan hasil penelitian dan beberapa temuan di lapangan, penulis menyarankan Lembaga pendidikan dapat menerapkan model pembelajaran SAVI untuk melatih keaktifan dan kemandirian belajar matematis peserta didik dalam proses pembelajaran. Model pembalajaran SAVI dapat meningkatkan keterlibatan peserta didik dalam aktifitas pembelajaran. Oleh karena itu disarankan kepada peserta didik untuk menerapkan model pembelajaran SAVI dalam pembelajaran matematika, sebagai alternatif dalam pembelajaran yang dapat meningkatkan kemampuan pemecahan masalah matematis peserta didik. Bagi penelitian selanjutnya disarankan untuk melihat peningkatkan setiap indikator kemampuan pemecahan masalah matematis dan kemampuan lainnya yang bisa diterapkan melalui model pemeblajaran SAVI. Semoga apa yang diteliti dapat dilanjutkan oleh penulis lain dengan penelitian yang lebih luas dan apa yang diteliti dapat memberikan manfaat serta sumbanagn pemikiran bagi pendidik pada umumnya dan khususnya bagi penulis terutama pada materi faktorisasi aljabar.

\section{DAFTAR PUSTAKA}

Afriawan, M., Binadjab, A., \& Latifahb. (2012). Pengaruh Penerapan Pendekatan SAVI Bervisi Sets pada Pencapaian Kompetensi Terkait Reaksi Redoks. UNNES Science Education Journal, 1(2), 50-59.

Alfiani, D. A. (2016). Penerapan Model Pembelajaran SAVI (Somatis, Auditori, Visual, Intelektual) Terhadap Hasil Belajar Anak Usia Dini. Awlady: Jurnal Pendidikan Anak, 2(1).

Amir, M. F. (2015). Pengaruh Pembelajaran Kontekstual terhadap Kemampuan Pemecahan Masalah Matematika Siswa Sekolah Dasar. In Prosiding Seminar Nasional Pendidikan: Tema "Peningkatan Kualitas Peserta Didik Melalui Implementasi (Pp. 34-42).

Arsani, N. K., Suarni, N. K., \& Kusmaryatni, N. (2017). Pengaruh Model Pembelajaran SAVI Berbantuan Gerakan Literasi Sekolah terhadap Hasil Belajar PKN Siswa Kelas IV. Mimbar Pgsd, 5(2), 1-12.

Astuti, R. P. S., Yuanita, P., \& Anggraini, R. D. (2018). Pengaruh Penerapan Pendekatan Pembelajaran Matematika Realistik (PMR) terhadap Kemampuan Pemecahan Masalah Matematika Siswa Kelas VII SMP Muhammadiyah 1 Pekanbaru. Jurnal Online Mahasiswa (JOM) Bidang Keguruan dan Ilmu Pendidikan, 5(1), 1-13.

Ayuningtyas, A. D. (2015). Eksperimentasi 
Desimal, 2 (2), 2019 - 127

Evi Dwi Murti, Nasir, Hasan Sastra Negara

Model Pembelajaran Kooperatif Tipe Think Pair Share (TPS) ditinjau dari Kemandirian Belajar Siswa Kelas VIII SMP Negeri di Kota Yogyakarta. Jurnal Ilmiah Pendidikan Matematika, 3(2), 452-466.

Dwi, I. M., Arif, H., \& Sentot, K. (2013). Pengaruh Strategi Problem Based Learning Berbasis ICT Terhadap Pemahaman Konsep dan Kemampuan Pemecahan Masalah Fisika. Jurnal Pendidikan Fisika Indonesia, 9(5), 8-17.

Fahradina, N., Ansari, B. I., \& Saiman. (2014). Peningkatan Kemampuan Komunikasi Matematis Dan Kemandirian Belajar Siswa Smp Dengan Menggunakan Model Investigasi Kelompok. Jurnal Didaktik Matematika, 1(1), 54-64.

Hakim, A. R. (2014). Pengaruh Model Pembelajaran Generatif terhadap Kemampuan Pemecahan Masalah Matematika. Jurnal Formatif, 4(3), 196-207.

Haruminati, N. W. Y., Suarni, N. K., \& Sudarma, I. K. (2016). Pengaruh Model Pembelajaran SAVI terhadap Minat Belajar Matematika Siswa Kelas IV SD Mutiara Singaraja. Jurusan PGSD, 4(1), 1-11.

Indrawan, K. A., Kristiantari, M. G. R., \& Negara, I. G. A. O. (2018). Pengaruh Model Pembelajaran Somatic Auditory Visualization Intellectualy Berbantuan Lingkungan Hidup Terhadap Hasil Belajar IPA Siswa. Jurnal Ilmiah Sekolah Dasar, 2(1), 59-67.

Irawan, D. (2015). Analisis Kemampuan Berpikir Kreatif Matematis dan Kemandirian Melalui Pembelajaran Model $4 K$ ditinjau dari Gaya Belajar Siswa Kelas VII (PHD Thesis). Universitas Negeri Semarang.

Khery, Y., \& Raodyatun, R. (2014). Respon
Dan Aktivitas Siswa dan Guru pada Penerapan Perangkat Pembelajaran Asam Basa dengan Pendekatan Somatis Auditori Visual Intelektual (SAVI). Hydrogen: Jurnal Kependidikan Kimia, 2(1), 161-165.

Kusumantara, K. S., Santyadiputra, G. S., \& Sugihartini, N. (2017). Pengaruh ELearning Schoology terhadap Hasil Belajar Simulasi Digital dengan Model Pembelajaran SAVI. Jurnal Pendidikan Teknologi dan Kejuruan, 14(2), 126-135.

Maulaholo, D. V. L., \& Haryudo, S. I. (2015). Pengaruh Model Pembelajaran SAVI (Somatis, Auditori, Visual, Intelektual) pada Mata Pelajaran Instalasi Motor Listrik terhadap Hasil Belajar Siswa Kelas XI TIPTL SMKN 3 Surabaya. Jurnal Pendidikan Teknik Elektro, 4(3), 1059-1065.

Muchlis, E. E. (2012). Pengaruh Pendekatan Pendidikan Matematika Realistik Indonesia (PMRI) Terhadap Perkembangan Kemampuan Pemecahan Masalah Siswa Kelas II SD Kartika 1.10 Padang. Jurnal Exacta, X(2), 136139.

Muslim, S. R. (2015). Pengaruh Penggunaan Metode Student Facilitator and Explaining dalam Pembelajaran Kooperatif terhadap Kemampuan Pemecahan Masalah Matematik Siswa SMK di Kota Tasikmalaya. Jurnal Penelitian Pendidikan dan Pengajaran Matematika, 1(1), 65-72.

Novianti, D. E. (2017). Profil Pemecahan Masalah Matematika dalam Menyelesaikan Permasalahan Pemrograman Linear Ditinjau dari Kemampuan Komunikasi Matematis Mahasiswa. JIPM (Jurnal Ilmiah Pendidikan Matematika), 6(1), 5359.

Noviyana, H., \& Fitriani, D. (2018). 
Desimal, 2 (2), 2019 - 128

Evi Dwi Murti, Nasir, Hasan Sastra Negara

Pengaruh Model Realistic Mathematics Education (RME) Terhadap Kemampuan Pemecahan Masalah Matematis Siswa Kelas VIII SMP. In Seminar Nasional Matematika dan Pendidikan Matematika (Pp. 385-392).

Nurhayati, N., \& Windayana, H. (2017). Pengaruh Pendekatan Pembelajaran Somatic, terhadap Kemampuan Pemahaman Matematis Siswa Sekolah Dasar. Antologi UPI, 5(1), 567-575.

Pratama, G. S., Nuryatin, A., Mardikantoro, H. B., \& Artikel, I. (2017). Pengembangan Perangkat Pembelajaran Menulis Deskriptif dengan Pendekatan SAVI Berbantuan Video Bagi Siswa SD, 6(1), 71-80.

Qohar, A. (2010). Mengembangkan Kemampuan Pemahaman, Koneksi dan Komunikasi Matematis serta Kemandirian Belajar Matematika Siswa SMP melalui Reciprocal Teaching (Phd Thesis). Universitas Pendidikan Indonesia.

Ramadhani, R. (2017). Peningkatan Kemampuan Pemahaman Konsep dan Kemampuan Pemecahan Masalah Matematikasiswa SMA melalui Guided Discovery Learning Berbantuan Autograph. 10(2), 7281.

Rosalina, E., \& Pertiwi, H. C. (2018). Pengaruh Model Pembelajaran SAVI. Jurnal Pendidikan Matematika (Judika Education), 1(2), 71-82.

Seruni. (2018). Pengaruh Model Pembelajaran terhadap Kemampuan Pemecahan Masalah. JKPM: Jurnal Kajian Pendidikan Matematika, 4(1), 35-42.

Setiawan, R. H., \& Harta, I. (2014). Pengaruh Pendekatan Open-Ended dan Pendekatan Kontekstual
Terhadap Kemampuan Pemecahan Masalah dan Sikap Siswa terhadap Matematika. Jurnal Riset Pendidikan Matematika, 1(2), 240-256.

Suratman, N. H. (2015). Penerapan Model Pembelajaran SAVI (Somatis Auditori Visual Intelektual) untuk Meningkatkan Keaktifan Belajar Siswa dalam Pembelajaran IPA Kelas III SD Negeri 1 Lebengjumuk Tahun 2015/2016 (S1). Universitas Muhammadiyah Surakarta.

Susanti, S., \& Nurfitriyanti, M. (2018). Pengaruh Model Realistic Mathematic Education (RME) terhadap Kemampuan Pemecahan Masalah Matematika. JKPM: Jurnal Kajian Pendidikan Matematika, 3(2), 115-122.

Sutarna, N. (2018). Pengaruh Model Pembelajaran SAVI (Somatic Auditory Visual Intellectualy) Terhadap Hasil Belajar Siswa Kelas IV Sekolah Dasar. Profesi Pendidikan Dasar, 5(2), 119-126.

Syazali, M. (2015). Pengaruh Model Pembelajaran Creative Problem Solving Berbantuan Maple II terhadap Kemampuan Pemecahan Masalah Matematis. Al-Jabar: Jurnal Pendidikan Matematika, 6(1), 91-98.

Wati, N. P. D. W., Darsana, I. W., \& Suardika, I. W. R. (2014). Pengaruh Model Pembelajaran Somatic, Auditory, Visual, Intelectual (SAVI) Berbantuan Bahan Ajar terhadap Hasil Belajar IPS Siswa Kelas V SD Gugus Raden Ajeng Kartini. Jurnal Mimbar PGSD Universitas Pendidikan Ganesha, 2(1).

Wati, N. P. D. W., \& Darsana, W. (2014). Pengaruh Model Pembelajaran Somatic, Auditory, Visual, Intelectual (SAVI) Berbantuan Bahan Ajar terhadap Hasil Belajar IPS Siswa Kelas V SD Gugus Raden Ajeng Kartini. Mimbar PGSD Undiksha, 2(1). 
Desimal, 2 (2), 2019 - 129

Evi Dwi Murti, Nasir, Hasan Sastra Negara

Wijayanti, T. F., \& Prayitno, B. A. (2013). Pengaruh Pendekatan SAVI melalui Model Pembelajaran Kooperatif Tipe Stad terhadap Hasil Belajar pada Siswa Kelas VII SMP Negeri 14 Surakarta. Pendidikan Biologi, 5(1), 1-14.

Wulandari, P., Mujib, \& Putra, F. G. (2016). Pengaruh Model Pembelajaran Investigasi Kelompok Berbantuan Perangkat Lunak Maple terhadap Kemampuan Pemecahan Masalah Matematis. Al-Jabar: Jurnal Pendidikan Matematika, 7(1), 101107.
Zulfah. (2017). Pengaruh Penerapan Model Pembelajaran Kooperatif Tipe Think Pair Share dengan Pendekatan Heuristik terhadap Kemampuan Pemecahan Masalah Matematis Siswa MTS Negeri Naumbai Kecamatan Kampar. Journal Cendekia: Jurnal Pendidikan Matematika, 1(2), 1-12. 